\title{
NAZWISKA W JĘZYKACH POLSKIM CZESKIM
}

\section{AGATA OSTROWSKA-KNAPIK}

\section{SURNAMES IN POLISH AND CZECH LANGUAGES}

ABSTRACT The article deals with the issues related to anthroponyms, namely surnames, and their place in the Polish and Czech linguistic system.

KEY WORDS surname, Czech language, Polish language

CONTACT Akademia Techniczno-Humanistyczna w Bielsku-Białej;

aostrowska@ath.bielsko.pl 
Trudno sobie w dzisiejszych czasach wyobrazić sytuację, że nazwiska nie są dziedziczone, członkowie jednego rodu różnie się nazywają, ludzie nie są tak silnie związani ze swoją nazwą rodziny, czy że nazwisko można zmieniać kilka razy w ciągu życia, w zależności od nabywanych wsi lub innych dóbr.

Zofia Kaleta-Kowalik w studium porównawczym „Ewolucja nazwisk słowiańskich" przedstawiła na podstawie dokumentów urzędowych z obszarów Czech, Polski, Chorwacji, Serbii, Bośni, Macedonii, Bułgarii oraz Rusi analizę rozwoju nazwisk od ich początków do czasów nowożytnych. Autorka wyróżniła pięć etapów ewolucji nazwisk: pierwszy - identyfikacja przez imię i tekst (do XII-XIII w.), drugi - przewaga odmiejscowych form syntetycznych (kraje zachodniosłowiańskie), trzeci - stabilizacja nazwisk słowiańskich, czwarty - ujednolicenie nazwisk według określonego wzoru morfologicznego oraz piąty - objęcie nazwisk przepisami i ochroną prawną, natomiast $w$ „Historii nazwisk polskich na tle społecznym i obyczajowym (XII-XV w.)" Kaleta-Kowalik wyodrębniła sześć typów nazwisk i przeprowadziła ich analizę pod względem słowotwórczym i mechanizmu ich powstania: „1. Nazwiska odmiejscowe (utworzone od nazw miejscowości, równe nazwom miejscowym, odmiejscowym wyrażeniom przyimkowym i nazwom mieszkańców). 2. Nazwiska patronimiczne (utworzone od nazwiska lub imienia ojca na oznaczenie syna). 3. Nazwiska odapelatywne (równe wyrazom pospolitym lub od nich utworzone). 4. Nazwiska odimienne (równe imionom chrzestnym pełnym lub formom od nich utworzonym). 5. Nazwiska odetniczne (utworzone od nazw etnicznych). 6. Nazwiska obcego pochodzenia (głównie niemieckie)" (Kaleta-Kowalik 2007: 13-14). W dokumentach źródłowych zachowały się formy nazwisk kobiet utworzone od nazwisk mężów lub ojców - i tak w przypadku nazwisk szlacheckich kobieta otrzymywała nazwisko zakończone na -ska (zmiana paradygmatu np. Jabłkowska (od: Jabłkowski), Orzewska (od: Orzewski), (Kaleta-Kowalik 2007: 341) lub tworzono (z męskiego nazwiska odapelatywnego) nazwisko w formie żeńskiej poprzez dodanie sufiksu -owa, -ina, wyjątkowo -ka, -ica, -icha np. Słyszowa (od: Słysz), Białuszyna (od: Białucha) (Kaleta-Kowalik 2007:342), jednak szlacheckich nosicielek tego typu nazwisk (zakonczonych na -owa, -ina) było znacznie mniej - w większości nosicielkami były mieszczanki oraz żony chłopów. W przypadku tej ostatniej warstwy społecznej nieliczne zapisy poświadczają dziedziczenie, obejmowanie generacji i przejmowanie nazwiska męża przez żonę do końca $\mathrm{XV}$ w. Podobnie, co do aspektu czasu, sytuacja przedstawiała się na ziemiach czeskich: „Nejdřive ustrnula osobní př́zviska v př́ijmení, t. j. ve jména rodů, u šlechty, pak u čelných měštanů, po nich u usedlých selských rodů a $\mathrm{p}$. $\mathrm{V}$ době neustálenosti př́imení někdy ani jednotlivec neměl př́ijmení po celý život stále stejné. Když se Jakub Váchů stal měštanem, přejmenovali ho sousedé př́ijmením Boží dopuštění a on toho jména potom beze všeho užíval. V Ohrazenicích u Turnova byl Jakub Červený pekař (1633 atd.) na rozdíl od jiných Červených zván a psán Pekař (1654); stal se zakladatelem tamějšího rodu Pekařủ. Jeho syn se r. 1687 jmenuje Červený, jinak Pekař" (Beneš 1944: 144). W Nowym Encyklopedycznym Słowniku Języka Czeskiego ${ }^{2}$ podano kolejne możliwości tworzenia dodatkowego - do imienia - antroponimu, przed wprowadzeniem

1 Kowalik-Kaleta Z., 1991, Ewolucja nazwisk słowiańskich: studium teoretyczno-porównawcze, Kraków, wydawnictwo Polskiej Akademii Nauk.

2 Nový encyklopedický slovník češtiny, @ Masarykova univerzita, Brno 2012-2018, słownik prowadzony przez Centrum zpracování přrirozeného jazyka, https://www.czechency.org/slovnik/P\%C5\%98\%C3\%8DJM\%C3\%8D, hasło opracowane przez Janę Pleskalovą CzechEncy. 
nazwisk: „(a) př́idomky / šlechtické predikáty - příjmí feudální šlechty podle sídel, popř. erbů (heraldické vlastní jméno); demonstrovaly držbu pozemků a statků, př́islušnost k rodu, urozenost a moc; (b) patronymika - identifikující pojmenovávaného prostřednictvím otcova jména, jeho zaměstnání, hodnosti: Jan Martinův; (c) metronymika - identifikující pojmenovávaného prostřednictvím matčina (manželčina) jména: Zikmund Mandin ,manžel Mandy'; (d) př́jimí podle domovních znaků ve městech - Václav od kapróv ,obyvatel domu U Kaprů’; (e) jména po chalupě - příjmí podle bývalých majitelů: Petr Matějka, dř. zapisovaný jako Petr na Matějkově gruntě. Po roce 1786 se vybraná př́jimí stávají př́jmeními, ostatní bud' slouží jako přezdívky či jména po chalupě, nebo zanikají. Výjimkou jsou šlechtické predikáty, které přežívaly do r. 1918, kdy bylo šlechtictví v Československu zrušeno“. Kobiety były nazywane w zależności od ich statusu społecznego. W większości przypadków nie brały udziału w czynnościach prawnych, zatem w dokumentach urzędowych były określane przy użyciu imienia/przydomka/nazwiska małżonka (Alžběta manželka Petra Drbala), rzadziej jej własnego, które miały częściej po ojcu (vydáno Kateřině Vachové do Lhoty). W przypadku owdowienia, kiedy kobieta przejmowała obowiązki męża, w dokumentach wpisywano jej identyfikację albo z pomocą różnych opisów (Anna manželka nebožtíka Peška; Anna manželka Šimkova), albo z pomocą derywowanej nazwy od przydomku/nazwiska małżonka (Alžběta Hanáková, Alžběta Hanákova, Manda Stolařka, Vyběhalka - manžel Vyběhal, Dorothea Linhartin [Linhartová]). Stopniowo przyjmuje się takie tworzenie określeń - przy zastosowaniu sufiksu -ov(-a), -ov(-á), - $k(-a)$, a w przypadku niemieckich przydomków/nazwisk -in-.

Pomimo wcześniejszych prób skodyfikowania obowiązku posiadania nazwiska (na ziemiach polskich projekt nazywany Kodeksem Stanisława Augusta oraz kodeks opracowany przez Andrzeja Zamoyskiego) prawnie obowiązujące stały się dopiero patenty wprowadzone W czasie, kiedy ziemie polskie były pod zaborami - Austria: patent Józefa II z 23 lipca 1787 r. ${ }^{3}$, patent Franciszka I z dnia 21 lutego 1805 r.; Prusy: edykty królewskie z 1796, 1797, 1812, Rosja: postanowienie księcia namiestnika z 27 marca 1821 r. (Świtała-Cheda, Cheda 2013: 651-652).

Obowiązek noszenia nazwiska wiązał się z zakazem zmiany jego formy ${ }^{4}$. Władze zaborcze wprowadziły zakaz używania nazwisk żon zakończonych na -owa, -ina, -ska, - $a$ oraz córek/ panien -ówna, -anka, -ska, -a. Władze polskie ustawą z 01. 08. 1919 r. zniosły ten zakaz. W okresie międzywojennym regionalne urzędy wojewódzkie nakazywały nawet stosowanie tego typu

3 1787, červenec 23. (patent); 1787, srpen 17. (dvorský dekret bez čísla); 1787, srpen 27. (guberniální nařízení č. 24366). Císař Josef II. vydává patent, na jehož základě jsou všichni rabíni s platností od 1. ledna 1788 povinni vést knihy narozených a obřezaných Židů pouze v německém jazyce a všichni narození, oddaní a zemřelí lidé musí být $v$ př́slušných knihách uvedeni s německým křestním jménem i př́jmením; $v$ případě nedodržení patentu hrozí rabínům pokuta ve výši 50 zl. a v případě opakování provinění sesazení s úřa$\mathrm{du}$ [w: Regestář všech tištěných konsistorních a vybraných ostatních písemností v náboženských a církevněpolitických záležitostech, vydaných za vlády Josefa II od 30. listopadu 1780 do 20 . února 1790 (sestavený podle dochovaných tišsěných pramenů $\mathrm{v}$ Kopiárích $\mathrm{z}$ fondu Archiv pražského arcibiskupství a vydaných dobových zákoníků)]

$4 \quad$ Szlachcie zwyczaj zmiany nazwiska, które było przyjmowane od nazwy włości, więc wraz ze zmianą dóbr ziemskich zmieniano też nazwisko np. Taczalski, który pochodził z Taczał, po przeniesieniu się do Krajkowa, nazywał się Krajkowskim, został zabroniony ustawą sejmową w 1600 r., w celu ułatwienia identyfikacji osób, por. Genealog Leszek Krajkowski: Po co szukamy przodków? Ze snobizmu, dla pieniędzy, Bartosz Nosal, 2 listopada 2012, https://poznan.wyborcza.pl/poznan/1,36001,12783431,Po_co_szukamy_ przodkow_Ze_snobi-zmu_dla_pieniedzy.html, data dostępu $10.03 .2020 \mathrm{r}$. 
form nazwisk kobiet i w okólnikach podawano zasady ich tworzenia (Litwin 1932: 24). Jednak obecnie nazwiska żeńskie używane są $\mathrm{w}$ formach bez ww. przyrostków. Ustawa z dnia 25 lutego 1964 Kodeks rodzinny i opiekuńczy dopuszcza w art. $25 \$ 2$ możliwość noszenia po zawarciu małżeństwa wspólnego nazwiska, które jest nazwiskiem dotychczasowym jednego z małżonków, możliwość pozostania przy swoim nazwisku oraz połączenia ze swoim nazwiska mężal żony pod warunkiem, że będzie się składało maksymalnie z dwóch członków. Nie została eksplicytnie określona kolejność takiego połączenia (najczęściej jednak pierwszym nazwiskiem jest nazwisko panieńskie, zapisywane $z$ łącznikiem ${ }^{5}$ ), ani że kobieta ma przyjmować nazwisko od męża z ewentualną zmianą paradygmatu, może się zatem nazywać np. Górski zamiast Górska. Konsekwencją jest następne nieodmienianie formy z niezmienionym paradygmatem zgodnie z zasadą, iż odmieniają się tylko nazwiska kobiet zakończone na - $a$ (nazwiska o zakończeniu -owa, -ewa odmieniają się tak jak przymiotniki, a pozostałe nazwiska żeńskie zakończone na -a odmieniają się tak jak rzeczowniki pospolite o podobnym zakończeniu).

Skudrzyk zauważa, że „nawet, jeśli przyrostki -anka czy -ówna wykorzystuje się do tworzenia nazwisk kobiet, to nie pełnią one już w zasadzie swej pierwotnej funkcji: nie tworzą nazwisk panien, kobiet niezamężnych", podając przykłady ze środowiska artystycznego Zającówna, Kucówna, Skarżanka, które noszą kobiety zamężne (Skudrzyk 1996: 19). Z kolei posłużenie się formą nazwiska z zakończeniem -owa, której to formy nosicielka zwykle nie używa, wprowadza „pewną familiarność, lokalność, mniejszy stopień oficjalności i prestiżu, przez co staje się nacechowana" (Skudrzyk 1996: 22). Podobną funkcję spełnia przekształcanie nazwisk nauczycielek przez uczniów w języku mówionym w środowisku szkolnym w formę nieoficjalną (np. zamiast Czudek - Czudkowa, zamiast Wawrosz - Wawroszowa) - forma męska odbierana jest jako formalna, oficjalna (Skudrzyk 1996: 22).

Ustawodawstwo czeskie reguluje tę kwestię odmiennie - po zawarciu związku małżeńskiego/partnerskiego kobieta nosi nazwisko z formantem -ová derywowanym zgodnie z zasadami gramatyki. W wyjątkowych sytuacjach (kiedy jest obcokrajowcem, obywatelką Republiki Czeskiej, która ma lub będzie mieć adres zameldowania za granicą, obywatelką Republiki Czeskiej, której mąż/partnerka jest obcokrajowcem, obywatelką Republiki Czeskiej posiadającą inną niż czeską narodowość) kobieta może pozostać przy męskiej formie nazwiska ${ }^{6}$. W przypadku łączenia nazwisk, na pierwszym miejscu jest nazwisko przybrane od męża, na drugim poprzednio noszone ${ }^{7}$, zapisywane bez łącznika ${ }^{8}$. Coraz częściej jednak dochodzi do dyskusji, sondaży, a także do prób wprowadzenia nowelizacji przepisów prawnych tak, by umożliwić kobietom podjęcie decyzji czy nazwisko odmężowskie będą przejmować z formantem -ová.

Formant czeski -ová i polski -owa Orłoś ${ }^{9}$ klasyfikuje jako czesko-polskie złudne ekwiwalenty słowotwórcze (Orłoś 2009: 242). W czeskim to formy nazwisk żon paní Nováková i córek slečna

5 Bez łącznika zapisywane są nazwiska góralskie, wskazujące na pochodzenie - nie stanowią złożenia nazwiska panieńskiego i mężowskiego.

6 https://www.mvcr.cz/clanek/jmena-a-prijmeni-zenska-prijmeni.aspx, data dostępu 10.03.2020 r.

7 Zákon č. 301/2000 Sb., o matrikách, jménu a př́imení a o změně některých souvisejících zákonů, ve znění pozdějších předpisů, $\$ 70$.

8 https://prirucka.ujc.cas.cz/?id=704, data dostępu 10.03.2020 r.

9 Teresa Zofia Orłoś odniosła się do zagadnienia polskich nazwisk i ich przyswajania przez tłumaczy $\mathrm{w}$ artykule Kłopoty z przyswajaniem polskich nazwisk w czeszczyźnie opublikowanym w „Studiach bohemistycznych. Część II" 1992, Kraków, wyd. Universitas, ISBN 83-7052-105-3. 
Nováková, w polskim jedynie nazwy żon pani Nowakowa, zaś kobieta niezamężna nazywałaby się panna Nowakówna.

Podobnie jak zaprzestano stosowania formantów -owa lub -anka, czy -ówna zaprzestano także zwracać się do kobiet niezamężnych panna zastępując ten zwrot panią. W języku czeskim nadal stosuje się zwrot slečno, chociaż w poradniku internetowym Internetová jazyková př́ručka zaleca się, by także w przypadku kobiet niezamężnych stosować neutralne (szanowna) pani ${ }^{10}$, W szczególności w komunikacji pisemnej. Z wypowiedzi kobiet na różnych forach internetowych ${ }^{11}$ wynika, że zamiana slečno na paní następuje również z chwilą urodzenia dziecka lub uzyskania tytułu zawodowego oraz że nie mają nic przeciwko takiemu zwracaniu się do siebie, chyba że ton nadawcy komunikatu zdradza chęć wywyższenia się. Kolejną różnicą dotyczącą form adresatywnych jest używanie $\mathrm{w}$ języku polskim imion, nie tak jak w języku czeskim nazwisk, coraz powszechniejsze staje się zwracanie do kogoś, nawet w przypadku krótkiej znajomości, Pani Aniu, Panie Marcinie. W kontaktach pisemnych należy używać zwrotów Szanowna Pani / Szanowny Panie / Szanowny Panie Redaktorze / Pani Kierownik (zawsze bez nazwiska). W komunikacji werbalnej forma szanowny panie jest niestosowna. W języku czeskim funkcjonuje zwrot pan/ pani z nazwiskiem w wołaczu (ewent. z tytułem, ale nie równocześnie z tytułem i nazwiskiem) paní Kučerová, pane Nováku, paní doktorko, pane doktore. Zastosowanie tutaj nazwiska mężczyzny w mianowniku (pane Novák) traktuje się jako oznakę nieformalności lub nieznajomości zasad. W języku polskim z kolei w relacji pan - pani zwracamy się proszę pana, proszę pani, ewent. pani dyrektor, panie doktorze. Podobnie jak zwracanie się do kogoś, zarówno w mowie jak i w piśmie, przy użyciu tylko nazwiska (w języku czeskim) lub nazwiska poprzedzonego formą pan (w języku polskim) odbierane jest jako nieuprzejmość i niegrzeczność: Nováková, uvařte mi kafe, prosím; Panie Kowalski, proszę o dokumenty.

W kontekście zwracania się do odbiorcy warto nadmienić jeszcze jedną możliwość - w języku czeskim formą pośrednią pomiędzy zwracaniem się do kogoś po imieniu lub na pan/pani jest używanie połączenia - zwrot po imieniu z użyciem form czasownika w 2. os. l. mn., które $\mathrm{w}$ języku czeskim stanowią odpowiedniki polskich form wyrażających zwracanie się w relacji pan - pani - państwo: Věruško, přineste mi prosím kávu; Jaroslave, udēlejte to, prosím.

$\mathrm{W}$ obliczu takich różnic w zapisie nazwiska, w jaki sposób oddawać je w tłumaczeniu? $\mathrm{W}$ oficjalnych dokumentach tłumacz podaje nazwisko $\mathrm{w}$ oryginalnym brzmieniu. Zgodnie z zasadą: „1. Nie należy tłumaczyć imion i nazwisk ani podawać ich odpowiedników w języku docelowym. Imiona odojcowskie należy przytaczać w niezmienionej formie"12. Zachowują zatem również znaki diakrytyczne. Zasadą jest także, iż w przypadku braku koniecznych znaków diakrytycznych w oryginale należy pominąć je równocześnie w tłumaczeniu, można dodać uwagę tłumacza o przytoczeniu oryginalnego zapisu. Oczywiście w przypadku alfabetów niełacińskich jest stosowana transliteracja. Uwagą tłumacza można posłużyć się także w przypadku, kiedy tłumacz ma wątpliwości co do formy nazwiska w mianowniku, kiedy w tekście występuje

10 jw.

11 https://www.emimino.cz/diskuse/pani-nebo-slecna-288852/, data dostępu 10.03.2020 r.; https:// www.omlazeni.cz/osloveni-slecna-pani-40-575007-0.html, data dostępu 10.03.2020 r.

12 Kodeks zawodowy tłumacza przysięgłego, red. Rybińska Z., Czyżewska M., Miler-Cassino J., Poznański J., Szędzielorz E., 2019, Warszawa, wyd, Polskie Towarzystwo Tłumaczy Przysięgłych i Specjalistycznych, ISBN 978-83-941503-2-7, s. 23-24. 
nazwisko w przypadkach zależnych, np. nie ma pana Dutki może wskazywać na dwa możliwe brzmienia nazwiska w mianowniku Dutko lub Dutka; Mówię o panu Hornie, może wskazywać na nazwisko w mianowniku: Horn, Horno, Horna. Nieodmienianie nazwiska jest błędem, nazwiska należy odmieniać, jednak praktyka językowa pokazuje, że w przestrzeni języka polskiego często podawane są nazwiska nieodmieniane - w formie mianownika. Może to wynikać $z$ różnych przyczyn: $\mathrm{z}$ braku wiedzy, z nieznajomości poprawnych form odmiany, obawy przed ośmieszeniem (może się wydawać, że formy bez pana Dąba, pana Mydela/Mydla i pana Oczki nie są poprawne i posługując się taką formą narazimy się zdziwienie odbiorcy), obawą urzędników lub prawników, że dojdzie do pomyłki oraz komputeryzacją, gdzie wpisywane są nazwiska tylko w mianowniku. Miodek uważa, że w mowie potocznej użytkownicy języka polskiego są bardziej skłonni do odmieniania: „Krąży jakaś fałszywa opinia, że w tekstach oficjalnych nazwisk się nie odmienia. Bo w życiu codziennym, w mowie żywej nie jest źle. Ludzie chodzą do Nowaka, przyglądają się Nowakowi, podchodzą do Widery, Pietraszki i Widerze albo Pietraszce coś dają. Ale jak teraz trzeba temu Nowakowi, Widerze albo Pietraszce dać dyplom, nagle następuje jakieś zdumiewające usztywnienie postaw gramatycznych i dyplom uznania jest ,dla Jana Nowak'. Ja to widzę na dyplomach, ja to widzę w dedykacjach uczniowskich, ja to widzę i słyszę w intencjach mszalnych!"13. Jednak obecnie - w czasie powszechnego dostępu do słowników poprawnej polszczyzny oraz Internetu zawsze można sprawdzić poprawność danej formy. Istnieją strony internetowe, gdzie można podać formę podstawową nazwiska, a odmiana zostanie podana automatycznie.

W tłumaczeniu dokumentów podaje się zatem w przypadkach zależnych końcówki odpowiedniego przypadka języka fleksyjnego, na który się tłumaczy Chtěl bych si sjednat schưzku s panem Kowalským; Umówiłem się na spotkanie z panem Horákiem. Trudność może pojawić się w przypadku polskich nazwisk kobiet w tłumaczeniu na język czeski Chtěl bych si sjednat schůzku s paní Knapikovou / paní Knapik [?]. Tutaj też można posłużyć się uwagą tłumacza i podać dodatkowo formę w mianowniku Chtèl bych si sjednat schůzku s paní Knapikovou [Knapik].

W języku czeskim, w przypadku kiedy nazwisko kobiety pozostanie w formie męskiej, nie jest odmieniane. Adam Kř́ı̌̌ ${ }^{14}$ zastanawia się, w jaki sposób zwracać się do pani, która oficjalnie ma zapisane w aktach stanu cywilnego Adéla Vácha - „V tomto případě by přicházelo v úvahu ještě skloňování podle vzoru „žena”. Obě možnosti ale působí zvláštně, nezvykle, či nepřirozeně. Nejlepším řešením je jméno přechýlit: pưjdu k Adéle Váchové. Je třeba si uvědomit, že zákon usměrňuje zápis jména pouze do matrik (a souvisejících dokumentů) a nevztahuje se na jiné oblasti uživání jména - proto se v novinových článcích apod. můžeme bez obav přiklonit k přechylování“. Zapisane w taki sposób pojawiają się także nazwiska znanych aktorek, piosenkarek zagranicznych czy innych znanych osobistości: Robertsová, Dionová, Merkelová, a na okładkach wydanych tłumaczeń literatury pojawiają się nazwiska autorek z sufiksem -ová: Olga Tokarczuková, Joanna Batorová, Hanna Krallová. Warto podkreślić, że zostało przyjęte, iż nazwiska niektórych znanych osób używane są tradycyjnie bez formantu -ová: Edith Piaf, Marilyn Monroe, Gina Lollobrigida ${ }^{15}$.

$13 \mathrm{https://plus.nto.pl/prof-jan-miodek-nazwiska-trzeba-odmieniac/ar/c1-4161843,} \mathrm{data} \mathrm{dostępu}$ $10.03 .2020 \mathrm{r}$.

14 Adam Kř́ž opracował m. in. hasło Jak v češtině správně prechylovat w publikacji Čeština nově od A do Ž pod red. Markéty Pravdovej, s. 132-133.

15 por. https://prirucka.ujc.cas.cz/?id=700, data dostępu 15.04.2020 r. 
W przypadku tłumaczenia literackiego tłumacz musi mieć świadomość, że nazwiska bardzo często są intencjonalne. Jak podaje Hejwowski ilustrując przykładami nazwisk bohaterów „Harrego Pottera”: Draco Malfoy, Longbottom, Remus Lupin czy Harry Potter „większości przytoczonych nazwisk - zwłaszcza w prozie realistycznej lub zawierającej wątki quasi-realistyczne - nie przetłumaczymy dzisiaj za pomocą polskojęzycznych ekwiwalentów apelatywów tworzących te nazwiska bądź wchodzących w ich skład, ale tłumacz musi sobie zdawać sprawę z roli takich imion własnych, a w uzasadnionych przypadkach [...] wyjaśnić tę rolę czytelnikom" (Hejwowski 2015: 134). Oprócz funkcji intencjonalnej bohaterowie literaccy mogą zostać obdarzeni nazwiskami spełniającymi funkcję opisową i aluzyjną. Wilkoń podaje, iż nazwy własne mogą w utworze literackim pełnić następujące funkcje: 1. lokalizacyjną umiejscowienie fabuły w określonym czasie i miejscu, 2. socjologiczną - wskazanie na przynależność społeczną, środowiskową, narodową postaci, 3. aluzyjną - do konkretnych osób lub miejsc, 4. treściową - charakteryzowanie postaci zgodnie z metaforycznym lub dosłownym znaczeniem nazwy, 5. ekspresywną - nazwa wyraża emocjonalne nastawienie autora i bohaterów, współtworzy klimat uczuciowy utworu (Wilkoń 1970: 83, Hejwowski 2015: 143). Z czasem powyższy wykaz funkcji został przez innych badaczy wzbogacony o kolejne: impresywną, emotywną, werystyczną, informacyjną, dydaktyczną, informacyjno-dydaktyczną, poetycką, wartościującą, intertekstualną, aluzyjną, kamuflażową, uniwersalizacyjną. Hejwowski zauważa, że obecnie większość nazwisk podlega transferowi i wyróżnia następujące techniki tłumaczenia: transfer w postaci czystej, transfer z modyfikacją graficzną, transfer z transkrypcją, transfer z modyfikacją adaptacyjną, transfer z objaśnieniem - przypis, zastosowanie nazwy podobnej graficznie bądź brzmieniowo, choć bez związku etymologicznego, zastosowanie nazwy własnej niezwiązanej z oryginalną ani etymologicznie, ani graficznie, ani brzmieniowo, zastosowanie ekwiwalentu funkcjonalnego, tłumaczenie za pomocą ekwiwalentów słownikowych, szczególnie w przypadku nazwisk intencjonalnych, zastąpienie opisowej nazwy własnej opisową nazwą własną w języku docelowym, która budzi podobne konotacje, zastąpienie realistycznej nazwy własnej nazwą intencjonalną, opuszczenie.

W niniejszym artykule przedstawiono wyniki przeprowadzonej analizy porównawczej, która miała na celu ukazanie różnic i podobieństw dotyczących antroponimów, konkretnie nazwisk, ich historii, pochodzenia, form nazwisk żeńskich i męskich, różnic kulturowych przejawiających się w zwracaniu się do adresata wypowiedzi oraz problematyki związanej z nazwami własnymi w tłumaczeniach. Zaprezentowano także techniki tłumaczenia, którymi tłumacze mogą się posłużyć w przypadku tłumaczenia zarówno dokumentów oficjalnych jak i tłumaczenia literackiego. Przedstawiono także odmienne rozwiązania prawne w przypadku zawarcia związku małżeńskiego i zmiany nazwiska w Rzeczypospolitej Polskiej i Republice Czeskiej.

Świadomość różnic kulturowych ustrzega przed popełnieniem błędu, zrażeniem sobie rozmówcy czy narażeniem na niepowodzenie przedsięwzięć zawodowych. Z pewnością ułatwia zrozumienie, obalanie mitów i walkę ze stereotypami, szczególnie tymi krzywdzącymi. Jest fascynujące i ciekawe. 


\section{SURNAMES IN POLISH AND CZECH LANGUAGES}

SUMMARY This article presents the results of a comparative analysis, which aimed to unveil the differences and similarities regarding anthroponyms, specifically surnames, their history, origin, forms of female and male surnames, cultural differences manifested in addressing the addressee of the utterance as well as the issues related to proper names in translation. The techniques of translation, which translators can use in translation of both official documents and literary translation, are presented. Various legal solutions in the event of entering a marriage and changing a name in the Republic of Poland and the Czech Republic are also demonstrated.

\section{LITERATURA}

I Beneš J., 2013, O našich př́imeních, „Naše řeč“, ročník 28 (1944), číslo 7.

I Hejwowski K., 2015, Iluzja przekładu, Katowice.

I Kowalik-Kaleta Z., 2007, Historia nazwisk polskich na tle społecznym i obyczajowym, T. 1, (XII-XV wiek), Warszawa.

I Litwin J., 1932, Imię nazwisko. Zbiór przepisów polskiego prawa cywilnego i administracyjnego, Łódź.

I Nový encyklopedický slovník češtiny, @ Masarykova univerzita, Brno 2012-2018, słownik prowadzony przez Centrum zpracování přirozeného jazyka, https://www.czechency.org/ slovnik. [data dostępu: 10.03.2020]

I Orłoś T. Z., 2009, Czesko-polskie złudne ekwiwalenty słowotwórcze, „Bohemistyka”, nr 4.

I Pravdová M. red., 2016, Čeština nově od A do Ž, Praga.

I Rybińska Z. - Czyżewska M. - Miler-Cassino J. - Poznański J. - Szędzielorz E. red., 2019, Kodeks zawodowy tłumacza przysiegtego, Warszawa.

I Skudrzyk A., 1996, Nazwiska żeńskie z przyrostkiem -owa we współczesnej polszczyźnie ogólnej, „Język Polski”, LXXVI, z. 1, s. 17-23.

I Świtała-Cheda M. - Cheda J., 2013, Zarys ewolucji nazwiska polskiego w historii języka i prawa, „Състояние и проблеми на българската ономастика”, т. 13, Велйко Тъेрново, s. 646-661, http://journals.uni-vt.bg/onom/bul/voli3/iss1/. [data dostępu: 10.03.2020]

I Ustawa z dnia 25 lutego 1964 r. Kodeks rodzinny i opiekuńczy Dz. U. $1964 \mathrm{Nr} 9$ poz. 59.

I Wilkoń A., 1970, Nazewnictwo w utworach Stefana Żeromskiego, Prace Onomastyczne 16, Wrocław-Warszawa-Kraków.

I Zákon č. 301/2000 Sb., o matrikách, jménu a přijmení a o změně některých souvisejicích zákonů, ve znění pozdějších predpisů.

I https://plus.nto.pl/prof-jan-miodek-nazwiska-trzeba-odmieniac/ar/c1-4161843. [data dostępu: 10.03.2020]

I https://prirucka.ujc.cas.cz/?id=704. [data dostępu: 10.03.2020]

I https://www.mvcr.cz/clanek/jmena-a-prijmeni-zenska-prijmeni.aspx. [data dostępu: 10.03.2020] 